University of Nebraska - Lincoln

DigitalCommons@University of Nebraska - Lincoln

USDA Wildlife Services - Staff Publications

U.S. Department of Agriculture: Animal and Plant Health Inspection Service

2015

Deer response to exclusion from stored cattle feed in Michigan, USA

\author{
Michael J. Lavelle \\ USDA/APHIS/WS National Wildlife Research Center, michael.j.lavelle@aphis.usda.gov \\ Henry Campa III \\ Michigan State University \\ Kyle LeDoux \\ Michigan State University \\ Patrick J. Ryan \\ United States Department of Agriculture, Animal and Plant Health Inspection Service, Wildlife Services, \\ Gaylord, MI
}

Justin W. Fischer

USDA/APHIS/WS National Wildlife Research Center, Justin.w.fischer@aphis.usda.gov

See next page for additional authors

Follow this and additional works at: https://digitalcommons.unl.edu/icwdm_usdanwrc

Part of the Life Sciences Commons

Lavelle, Michael J.; Campa, Henry III; LeDoux, Kyle; Ryan, Patrick J.; Fischer, Justin W.; Pepin, Kim M.; Blass, Chad R.; Glow, Michael P.; Hygnstrom, Scott E.; and VerCauteren, Kurt C., "Deer response to exclusion from stored cattle feed in Michigan, USA" (2015). USDA Wildlife Services - Staff Publications. 1705.

https://digitalcommons.unl.edu/icwdm_usdanwrc/1705

This Article is brought to you for free and open access by the U.S. Department of Agriculture: Animal and Plant Health Inspection Service at DigitalCommons@University of Nebraska - Lincoln. It has been accepted for inclusion in USDA Wildlife Services - Staff Publications by an authorized administrator of DigitalCommons@University of Nebraska - Lincoln. 


\section{Authors}

Michael J. Lavelle, Henry Campa III, Kyle LeDoux, Patrick J. Ryan, Justin W. Fischer, Kim M. Pepin, Chad R. Blass, Michael P. Glow, Scott E. Hygnstrom, and Kurt C. VerCauteren 


\title{
Deer response to exclusion from stored cattle feed in Michigan, USA
}

\author{
Michael J. Lavelle ${ }^{\mathrm{a}, *}$, Henry Campa III ${ }^{\mathrm{b}}$, Kyle LeDoux ${ }^{\mathrm{b}}$, Patrick J. Ryan ${ }^{\mathrm{c}}$, Justin W. Fischer ${ }^{\mathrm{a}}$, \\ Kim M. Pepin ${ }^{\mathrm{a}}$, Chad R. Blass ${ }^{\mathrm{a}}$, Michael P. Glow ${ }^{\mathrm{d}}$, Scott E. Hygnstrom ${ }^{\mathrm{d}}$, \\ Kurt C. VerCauteren ${ }^{\mathrm{a}}$ \\ a United States Department of Agriculture, Animal and Plant Health Inspection Service, Wildlife Services, National Wildlife Research Center, 4101 LaPorte \\ Avenue, Fort Collins, CO 80521-2154, USA \\ b Department of Fisheries and Wildlife, Michigan State University, East Lansing, MI 48824, USA \\ ' United States Department of Agriculture, Animal and Plant Health Inspection Service, Wildife Services, 1865 O'Rourke Boulevard, Gaylord, MI 49735, USA \\ d College of Natural Resources, University of Wisconsin-Stevens Point, Stevens Point, WI 54481, USA
}

\section{A R T I C L E I N F O}

\section{Article history:}

Received 20 April 2015

Received in revised form 15 June 2015

Accepted 16 June 2015

\section{Keywords:}

Biosecurity

Bovine tuberculosis

Cattle

Fence

Pathogen transmission

White-tailed deer

\begin{abstract}
A B S T R A C T
Disease and damage from white-tailed deer (Odocoileus virginianus) continually threaten the livelihood of agricultural producers and the economy in the United States, as well as challenge state and federal wildlife managers. Threats can be partially addressed by excluding free-ranging deer from livestock-related resources. Throughout the year, use of stored livestock feed by deer in northern Lower Michigan (MI), USA fluctuates, though their presence is relatively consistent. Since 2008, use of livestock areas and resources by deer has been reduced through intensive efforts by livestock producers in cooperation with state and federal agencies. These efforts focused on excluding deer from stored cattle feed in areas where deer were abundant. We monitored deer activity from Jan 2012 to June 2013 on 6 cattle farms in northern MI using GPS collars to evaluate behavioral effects of excluding deer from stored feed. We characterized areas deer occupied before and after installing $2361 \mathrm{~m}$ of fences and gates to exclude deer from stored cattle feed. Following fence installation, 9 deer previously accessing stored feed shifted to patterns of habitat use similar to 5 deer that did not use stored feed. However, continued attempts to regain access to stored feed were made at low frequencies, emphasizing the need to maintain the integrity of fences and keep gates closed for damage prevention and biosecurity.
\end{abstract}

Published by Elsevier B.V.

\section{Introduction}

Wildlife species frequently exploit accessible high-quality feed destined for livestock (VerCauteren et al., 2003; Atwood et al., 2009; Tsukada et al., 2010). Contamination of livestock feed by wildlife often occurs as well, rendering feed unusable and creating a source for dissemination of pathogens (Daniels et al., 2003; VerCauteren et al., 2003; Tsukada et al., 2010). A primary concern of livestock producers and wildlife managers in northeastern Lower Michigan (MI), USA is the potential for contamination of stored feed with bovine tuberculosis (bTB) bacteria (Mycobacterium bovis) by infected white-tailed deer (Odocoileus virginianus; Palmer et al., 2004a,b; Knust, 2008).

\footnotetext{
* Corresponding author at: USDA/APHIS/WS/National Wildlife Research Center, 4101 LaPorte Avenue, Fort Collins, CO 80521-2154, USA. Fax. 9702666089.

E-mail address: michael.j.lavelle@aphis.usda.gov (M.J. Lavelle).
}

Many methods for deterring deer exist, though relative levels of efficacy vary considerably along with associated costs, maintenance, longevity, and ease of use (VerCauteren et al., 2006a,b, 2008; Brook, 2010). The level of motivation of deer to breach exclusionary installations usually is the primary factor in resulting efficacy (Gilsdorf et al., 2002; VerCauteren et al., 2006a, 2010; Lavelle et al., 2010). During winter and other periods of increased nutritional needs (i.e., parturition, gestation), deer become highly motivated to gain access and consume feed stored for cattle, focusing on feed of high nutritional value (VerCauteren et al., 2003; Knust, 2008). To minimize access to high quality feed by deer, various proven fence designs are available (VerCauteren et al., 2006a; Knust, 2008; Lavelle et al., 2010). We assessed the effects of installing exclusionary fences around stored cattle feed by monitoring deer visitation rates to these sites as well as in adjacent land cover types before and after installation. Our objectives were to: (1) evaluate the efficacy of exclusionary fences on deer activity at the stored feed, and (2) examine whether the fences caused shifts in deer home range size or land cover usage patterns. 


\section{Materials and methods}

\subsection{Study area}

We conducted our study on 6 privately owned cattle operations in the northeastern Lower Peninsula of MI, USA within Montmorency, Presque Isle, and Alpena Counties. Average size of cattle operations was 169 ha $(S D=73.84)$ and 210 cattle $(S D=222.13)$. This area was within the core endemic area of bTB in MI (Walter et al., 2012; Berentsen et al., 2013) and provided highly suitable habitat for deer (Felix et al., 2007). We condensed land cover types in our study areas into five classes: (1) stored feed, including all developed areas associated with stored feed sites; (2) farmyard, including roads, buildings, animal pens, and residential homes; (3) cattle pasture, including grassy areas devoted to cattle grazing; (4) natural areas, including upland and lowland forests, wetlands, and shrub or scrub stands, and (5) crops, including all row crops and alfalfa. Although livestock production occurs in this area, densities were low, only averaging 1 beef-cattle farm per $21.5 \mathrm{~km}^{2}$ and 1 dairy-cattle farm per $130.0 \mathrm{~km}^{2}$ (Berentsen et al., 2013). Elevations range from 150 to $390 \mathrm{~m}$ above sea level with annual precipitation averaging $72.5 \mathrm{~cm}$ of rain and $175 \mathrm{~cm}$ of snow (Sitar, 1996). Winter snow depths seldom exceed $50 \mathrm{~cm}$, usually melting by mid-April (Beyer et al., 2010). Weather in this region was notably more variable than elsewhere in the state with average summer temperatures of $24.8^{\circ} \mathrm{C}$ and average winter temperatures of $-10.8^{\circ} \mathrm{C}$ (Sitar, 1996). Regional deer densities were estimated at 10 deer $/ \mathrm{km}^{2}$ (O'Brien et al., 2011), although concentrations of deer around accessible food during winter reached $19 \mathrm{deer} / \mathrm{km}^{2}$ (Beyer et al., 2010) and have been reported as high as $35 \mathrm{deer} / \mathrm{km}^{2}$ (Sitar, 1996). In conjunction with the estimated deer densities the apparent bTB prevalence rates in deer in the region fluctuated around $2 \%$ (O’Brien et al., 2011).

\section{Fence design and construction}

Experimental treatments in the form of exclusionary gates and fences were installed around stored livestock feed accessible to deer at all study sites, thus applied to all study animals within the vicinity. More specifically, we constructed fences or installed gates on existing structures to enclose stored feed and exclude deer ("exclosure" hereafter). A fence contractor prepared all sites and installed posts prior to installing fence to facilitate simultaneous construction of fences across sites and to minimize potential confounding factors such as weather. All fence installation was completed in January 2013 after deer use of stored feed had been documented.

Construction and design varied to fit requirements unique to each site and cattle producer. Fence material (Black Plastic Net; Kencove Farm Fence Supplies, Blairsville, PA) was provided to cooperating producers at no cost. If producers elected to install a more permanent fence, they could substitute woven-wire mesh (i.e., Solidlock ${ }^{\circledR}$ Game Fence 2096-6; Bekaert, Marietta, GA) at their expense. We installed plastic mesh fences at 2.0-m high (with 0.1$\mathrm{m}$ fence material draped on ground outside the stored feed to deter entry) and woven-wire mesh tight to the ground and 2.4-m high. We attached plastic mesh with hog rings at $1-\mathrm{m}$ increments to $12-$ ga high-tensile-steel wire run at ground level, $0.9 \mathrm{~m}$, and $2.0 \mathrm{~m}$. Having sufficient rigidity, woven-wire mesh was attached directly to wood posts with 4-cm galvanized-steel staples. Gate and corner posts, as well as in-line h-braces (every $100 \mathrm{~m}$ ) were constructed of treated wooden posts $(10.2-\mathrm{cm}$ or $15.2-\mathrm{cm}$ square and $3.0-\mathrm{m}$ long) set $0.6-\mathrm{m}$ deep in concrete $3-\mathrm{m}$ apart and connected by horizontal $10.2-\mathrm{cm}$ square posts with diagonal wire strainers. Gates were fabricated by a local contractor and consisted of $2.13-\mathrm{m}$ tall welded 3.5-cm diameter galvanized-steel pipe frames covered with woven-wire mesh. Following installation, we conducted weekly inspections of fences at each site and made necessary adjustments and repairs as needed.

\section{Site-specific details}

Site 1: We constructed a 491-m long, 2.4-m tall, woven-wire mesh fence (1.16-ha) on 23 January 2013 to protect high moisture corn, silage, and round hay bales. Land cover types adjacent to the farm were dominated by: $47 \%$ natural areas and $43 \%$ crops.

Site 2: We installed six 2.3-m tall gates on a pre-existing 0.04 -ha metal pole barn on 24 January 2013 to protect round hay bales. Land cover types adjacent to the farm were dominated by: $65 \%$ natural areas and $32 \%$ crops.

Site 3: We constructed a 709-m long, 3.10-ha, 2.0-m tall plastic mesh deer fence on 19 January 2013 to protect high moisture corn, haylage, and silage. Land cover types adjacent to the farm were dominated by: $53 \%$ natural areas and $41 \%$ crops.

Site 4: We constructed a 623-m long, 1.48-ha, 2.0-m tall plastic mesh deer fence on 30 January 2013 to protect high moisture corn, haylage, round hay bales, and silage. Land cover types adjacent to the farm were dominated by: $53 \%$ crops and $45 \%$ natural areas.

Site 5: We constructed a 709-m long, 3.10-ha 2.0-m tall, plastic mesh deer fence on 15 January 2013 to protect silage, beets, and potatoes. Land cover types adjacent to the farm were dominated by: $71 \%$ natural areas, $15 \%$ crops, and $13 \%$ cattle pasture.

Site 6: We completed (added 2 gates) a pre-existing 623-m long, 1.48-ha, 2.3-m tall 4-strand electrified poly-rope fence on 30 January 2013 to protect round hay bales. Land cover types adjacent to the farm were dominated by: $71 \%$ natural areas and $28 \%$ crops.

\section{Deer capture and monitoring}

Movements of deer were monitored before and after fence installation to evaluate behavioral effects of excluding them from stored feed resources. To achieve this, we captured and collared free-ranging adult female deer with netted cage traps (VerCauteren et al., 1999), air-cannons (Schemnitz et al., 2009), and remote chemical immobilization (Kilpatrick et al., 1997) primarily in January of 2012 and 2013, though also as needed throughout the study to maintain $\geq 3$ collared deer per site. Trap locations were dispersed across suitable habitat on each farm, thus all deer were considered potential study animals. Collared deer were located weekly with very high frequency (VHF) receivers and observed when possible to ensure good health and collar fit was maintained throughout the study. We used VHF-equipped GPS collars (TGW-4501, Telonics, Inc., Mesa, $\mathrm{AZ}$ ) to record locations of deer every $2 \mathrm{~h}$ for the duration of the study and used programmed collar-release mechanisms (CR2a, Telonics, Inc., Mesa, Arizona, USA) to facilitate data retrieval at the conclusion of the study. Accuracy testing of GPS collars at a fixed location ( $n=348$ fixes) revealed a median position error of $8.5 \mathrm{~m}$ and a $95 \%$ circular error of probability of $21.4 \mathrm{~m}$. All procedures were approved by the Institutional Animal Care and Use Committee of the U.S. Department of Agriculture-Animal and Plant Health Inspection Service-Wildlife Services-National Wildlife Research Center (USDA-APHIS-WS-NWRC, QA-1940) and conducted under Michigan Department of Natural Resources Scientific Collector's Permit SC1455.

\section{Data processing}

We focused all analyses to within 120 days before and 120 days after installation of fences. We also ran all of our analyses with 30-day periods before and after fence installation to determine if 
the longer 120-day period included too much variation to detect an effect of the fence. All results were identical in significant findings, therefore we only report our 120-day analyses. Individual deer were our experimental units, thus we further reduced our final dataset to eliminate non-independent samples resulting from deer pairs exhibiting correlated movements (Schauber et al., 2007). We also differentiated between non-migrant and migrant deer, thus excluded deer that were absent from the farm $\geq 30$ days (migrants) to eliminate potential confounding movement data due to seasonal migration. Post-hoc determination of treatment versus control deer was based on whether GPS locations indicated visitation to stored feed prior to installation of fences (Gulsby et al., 2011). Further, as deer capture was distributed across study sites and pre-fence use of stored feed was beyond our control, assignment of treatment level was considered random. We omitted the first 7 days of GPS data to limit potential bias resulting from capture and handling. We also discarded any locations with poor locational confidence(Dilution of precision >10) (Berentsen et al., 2013). To evaluate potential shifts in habitat use by deer following installation of fences and gates, we only used locations recorded between 1900 and 0700 (i.e., nocturnal locations), focusing our analyses on periods when deer are most active and feeding.

\section{Data analysis}

Changes in habitat use due to fence installation were analyzed using a generalized linear mixed model (GLMM) using the lme4 package in $\mathrm{R}$ (Version 3.0.1; R Foundation for Statistical Computing, Vienna, Austria). We condensed all available land cover types within the range of deer movements into 5 categories that likely pose differing levels of risk for disease spillover to cattle: stored feed, farmyard, occupied cattle pasture, natural habitat, and crops. Our response variable was the difference between the proportion of locations in each land cover type during the 120-day time period after fences were installed and the proportion of locations in each land cover type for 120 days prior to fences being installed (i.e., positive differences are an increase in use post-fence). For each land cover type except the stored feed, we used a normal distribution to model the effects of treatment on the after-before fence differences. For stored feed and any land cover type where treatment deer and control deer had significant differences in use we used an arc-sine square root transformation and a normal distribution to model the difference between the proportion of locations by treatment deer to stored feed before and after the fence. In both types of models we included individual farms as a random effect to account for correlated errors due to more similar behavior among deer from the same farm. Similarly, in the analysis of visitation to stored feed, where we compared before and after visitation frequencies (i.e., repeated measures), we also included individual deer as a random effect to account for error correlations due to repeated measures on the same individual.

To evaluate space use effects of exclosures on deer activity, we used 3 separate a priori approaches to identify shifts in space use potentially suggesting a treatment effect. First, for each period, we calculated home ranges (95\%) and core use areas (50\%) using a biased random bridge approach, or a movement-based kernel density estimator (MKDE), to estimate utilization distributions (UD; Benhamou and Cornelis 2010; Benhamou, 2011). The MKDE incorporates movement trajectories and accounts for serial autocorrelation of relocations when estimating UDs. We set the upper time limit for GPS fixes to be included in the analysis at $6 \mathrm{hrs}$ and considered locations less than $50 \mathrm{~m}$ apart to be inactive. We used the adehabitat package in $\mathrm{R}$ (Version 3.0.1; R Foundation for Statistical Computing, Vienna, Austria) to compute MKDE UDs. Second, we calculated the mean geographic center of GPS fixes, using
ArcGIS 10.0 (Environmental Systems Research Institute, Redlands, CA, USA), during each period and compared the distance from the center of the stored-feed exclosure to the center of the fixes for each period to estimate shifts toward or away from the exclosure (Gulsby et al., 2011). As in the land cover usage analysis, we calculated the difference between the after and before-fence estimates and used a GLMM with a normal distribution and farms as random effects.

\section{Results}

Overall, we collected complete data (i.e., having both 120 days pre- and post-fence) from 19 healthy individual adult female deer, including 9 resident treatment deer, 5 resident control deer, 1 migrant treatment deer, and 4 migrant control deer. We documented visitation rates to stored feed by 11 deer on 4 farms during the study; however, one migrant and another lacking independence (i.e., apparent members of same social group) were excluded from analyses. Visitation to stored feed was quite variable though common until fences were installed. After fences were installed, nocturnal habitat use by deer differed between control and treatment deer in only 2 cover types (Fig. 1$)$, farmyard $(\beta=-0.004$, $\mathrm{SE}=0.002)$ and cattle pasture $(\beta=-0.033, \mathrm{SE}=0.015)$. Additionally, use was significantly reduced in stored feed $(\beta=-0.185, \mathrm{SE}=0.057)$ and farmyard $(\beta=-0.039, \mathrm{SE}=0.015)$ by treatment deer after the fences were installed. Yet, deer continued to gain access through gates occasionally left open by producers which is reflected in our $<100 \%$ exclusion of deer at stored feed. Motion-activated cameras at one farm recorded deer lingering outside recently closed gates and passing through opened gates within $30 \mathrm{~min}$ of producer activity (Fig. 2). Use was not significantly reduced in cattle pastures $(\beta=-0.060, \mathrm{SE}=0.033)$. In relative terms, the estimated $8.21 \%$ reduction in stored feed visitation by treatment deer corresponded to an average reduction of $82.5 \%$ relative to before the fence was erected. Treatment and control deer did not significantly differ in use of the other 2 land cover types, natural areas $(\beta=-0.066$, $\mathrm{SE}=0.072)$ and $\operatorname{crops}(\beta=0.093, \mathrm{SE}=0.083)$.

Average distance from stored feed to mean geographic centers for control deer was $956 \mathrm{~m}(\mathrm{SE}=231.323)$ and treatment deer was $535 \mathrm{~m}(\mathrm{SE}=45.574)$ before installation of fences, with no significant change before and after the fence ( $\beta=51.20, \mathrm{SE}=222.20$; Fig. 3 ). Average pre-fence core range for control deer was $18.265 \mathrm{~km}^{2}$ $(\mathrm{SE}=3.250)$ and treatment deer was $29.464 \mathrm{~km}^{2}(\mathrm{SE}=2.681)$, again with no significant change from pre-fence to post-fence periods $(\beta=-1.118, \mathrm{SE}=9.116)$. Average pre-fence home range of control deer was $106.279 \mathrm{~km}^{2}(\mathrm{SE}=12.675)$ and treatment deer was $147.489 \mathrm{~km}^{2}$ (SEn=13.960), also with no significant change from pre-fence to post-fence periods ( $\beta=14.66, \mathrm{SE}=33.99$ ).

\section{Discussion}

Our results from GPS locations demonstrated that fences and gates excluded deer from stored feed and reduced visitation to farmyards. During routine fence inspections, however, we occasionally observed deer and tracks of deer that revisited stored feed sties and attempted to gain access following installation of fences and gates (see also Brook, 2010). Similarly, it was found that deer with established home ranges maintain those home ranges, even after being disrupted by installation of exclusionary fences (Gulsby et al., 2011). Further, our findings demonstrated the persistence to continue accessing habitually used resources by deer even after human intervention. Removal of persistent individual deer may eliminate potential for contamination by those particular individuals as well as reduce potential for learning by other deer. Alternatives to traditional gates, such as automatically clos- 


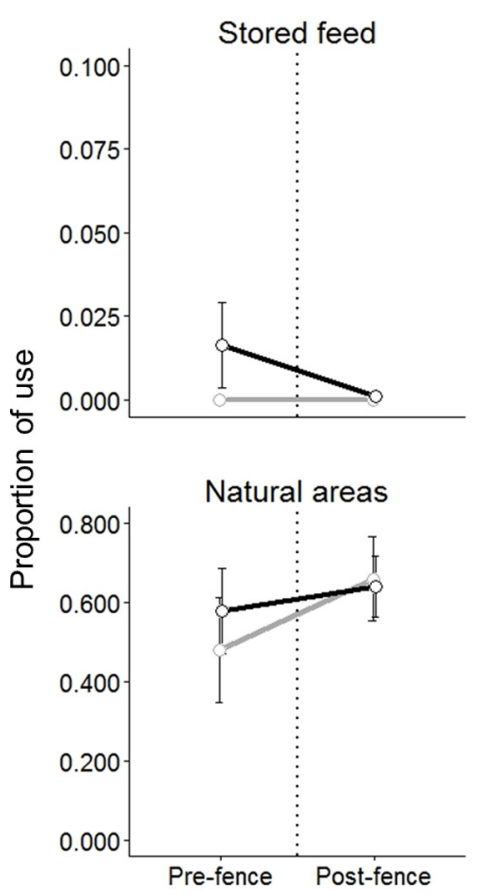

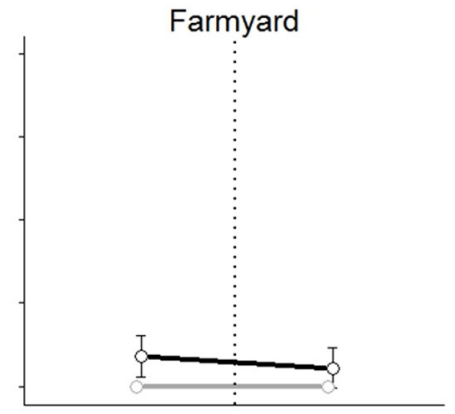

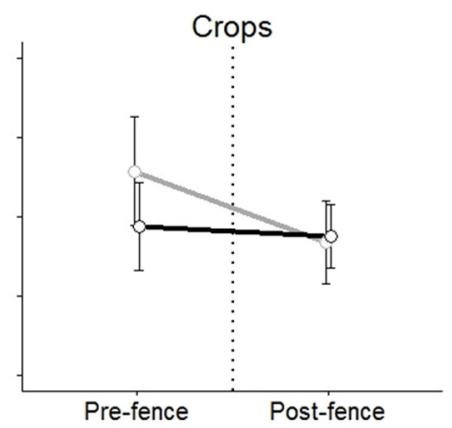

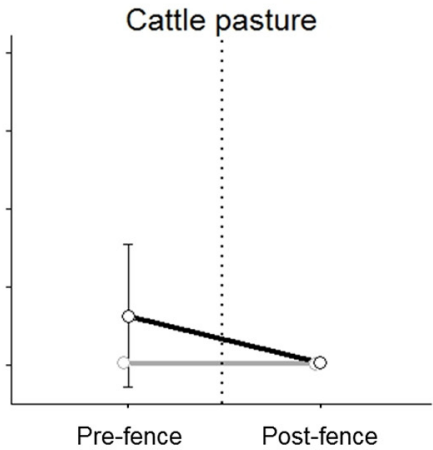

Pre-fence
Post-fence

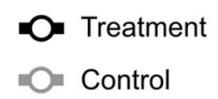

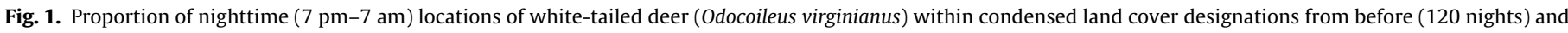

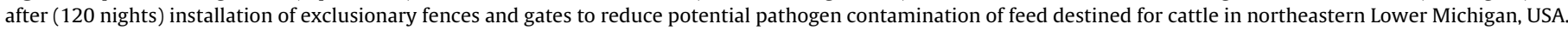

ing bump gates have demonstrated potential for excluding deer while still facilitating vehicular access to stored feed (VerCauteren et al., 2009; Berentsen et al., 2010).

In wildlife damage situations in which non-lethal management strategies are implemented, potential exists for simply displacing use to other accessible resources within their home range (Tolhurst et al., 2008; Judge et al., 2011). By the time we conducted our study, nearly all livestock producers within northeastern Lower MI (98\%) had already implemented exclusionary measures thus minimizing the possibility of deer shifting to other comparable stored feeds. After we excluded non-independent and migratory deer, the initial change in habitat use by treatment deer after the fences were constructed was an increased occupancy in natural areas. This pattern was similar in control deer, indicating that this shift in habitat use was likely caused by factors other than the fence being installed (e.g., seasonal changes in use, behavior, forage availability).

Since its inception in 1933, bTB, has repeatedly plagued cattle producers in North America (e.g., Cosgrove et al., 2012; Miller and Sweeney, 2013; Palmer, 2013). In the northern portion of the Lower
Peninsula of MI, bTB spilled into and is currently maintained in freeranging white-tailed deer, providing a source for reinfection and perpetuation of the problem (O'Brien et al., 2006; Fitzgerald and Kaneene, 2013). Deer-to-cattle interactions are rare (Hill, 2005), suggesting that pathogen transmission risk through direct interaction is less of a concern than indirect transmission through shared use of common resources such as stored feed (Portacci et al., 2009; Walter et al., 2012; Berentsen et al., 2013). Allowing potentially infected wildlife access to stored feed appears to be the most plausible means for bTB transmission (Palmer and Whipple, 2006; Ward et al., 2006; Walter et al., 2012). Development and implementation of methods for reducing transmission events are essential for effective suppression of bTB. Our study supports the hypothesis that when properly used, well-constructed exclusionary fences and gates may eliminate a plausible route for transmission of $M$. bovis from deer to cattle (Judge et al., 2006, Tolhurst et al., 2008).

Management of disease and damage involving wildlife often requires an integrated management approach in which several methods are used in combination to achieve a goal (DeNicola et al.,

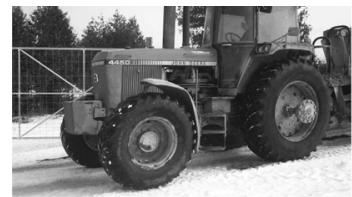

Gate open 11:08

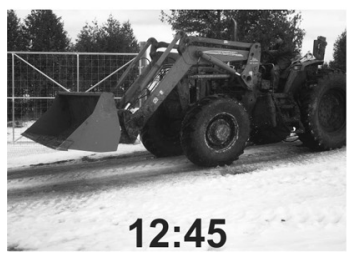

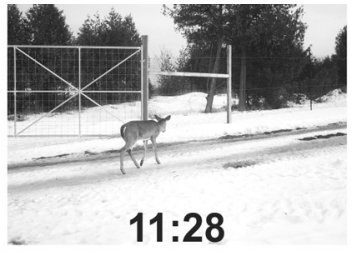

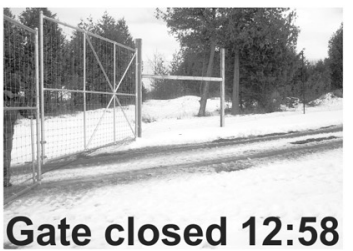

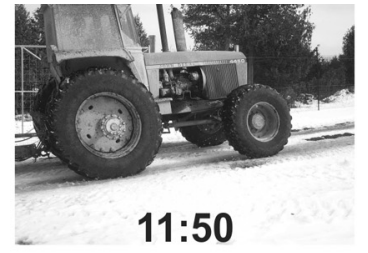
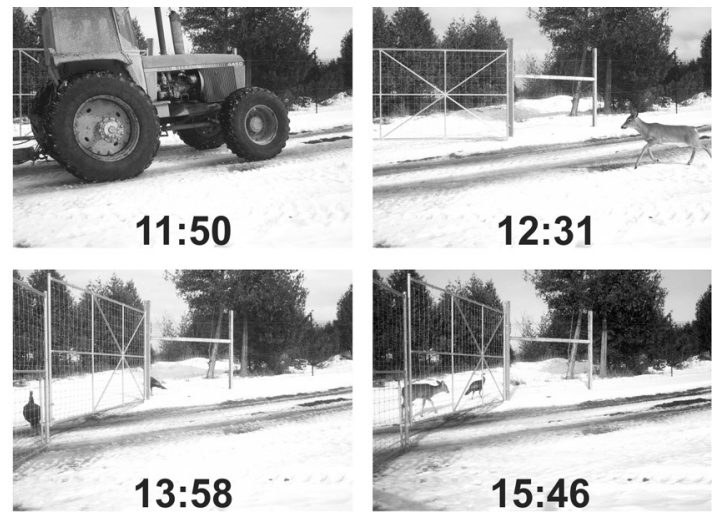

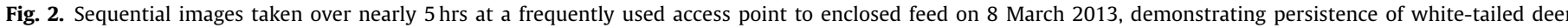

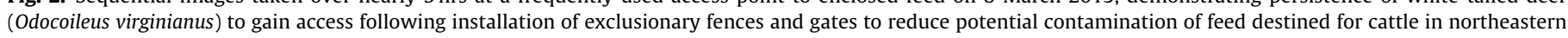
Lower Michigan, USA. 

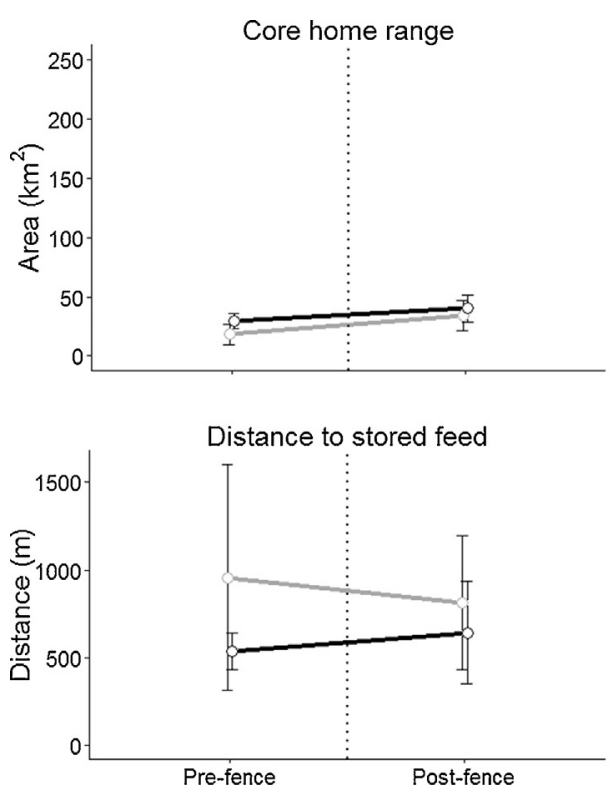

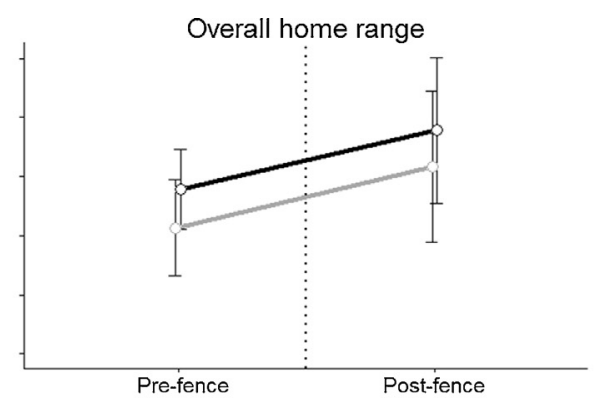

Oreatment Control

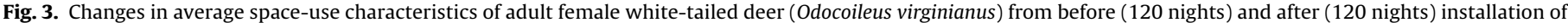
exclusionary fences and gates to reduce potential contamination of feed destined for cattle in northeastern Lower Michigan, USA.

2000; Lees, 2004; Putman et al., 2011; Cosgrove et al., 2012). Typical strategies for suppressing bTB in Michigan include fences to exclude deer from stored feed, fences to exclude cattle from wetlands, and practices such as providing only enough feed that cattle will eat in one day (Walter et al., 2012). Of these methods, eliminating access to feed by deer addresses contamination of feed, thereby minimizing risk of indirect pathogen transmission from deer to cattle (Okafor et al., 2011). Well-maintained fences and closed gates can be straightforward and effective means for eliminating access to stored feed, although they are costly and require considerable labor to install and maintain (VerCauteren et al., 2006a,b). Temporary and less-expensive deterrents are available, though extent and duration of efficacy are typically lower than exclusion with fences. For example, livestock protection dogs comingling with cattle (VerCauteren et al., 2008; Gehring et al., 2010), a round-bale feeder protection device (Seward et al., 2007), and species-specific gates that allow exclusive access to resources by livestock (VerCauteren et al., 2009; Barasona et al., 2013) have demonstrated promise in reducing potential for pathogen transmission. As with all nonlethal techniques, motivation of the offending animals must be considered when selecting appropriate strategies (VerCauteren et al., 2006a, 2010).

Disease management strategies such as those used in this study have wide-spread utility worldwide in situations where risk of inter-species transmission of disease exists at the wildlife-livestock interface (Barasona et al., 2013; Gortazar et al., 2015). For example, in Spain where potentially bTB-infected wild boar and domestic cattle share water sources, fences with species-specific gates have proven effective in minimizing shared use (Barasona et al., 2014). Additionally, temporary fences like plastic mesh can quickly provide a barrier for sporadic, transient, or seasonal needs that are associated with spatially confined focal sites (Lavelle et al., 2010, 2011; Barasona et al., 2014; Gortazar et al., 2015).

\section{Conclusion}

Suppression of bTB in MI has improved considerably in the last decade, especially due to the implementation of intensive efforts to segregate cattle and deer and reduce antlerless deer numbers. When high-quality feed is stockpiled and stored for future use in areas adjacent to deer habitat, deer often find and attempt to exploit these resources. Installation and maintenance of exclusionary fences and gates minimizes contamination of stored feed and unnatural concentrations of deer, thereby reducing the risk of deer-pathogen transmission. Although fences used in disease management efforts are in no way new or innovative, they are highly effective when used with vigilance. When integrated with other management strategies, such as focusing on reducing the number of antlerless deer, MI may be able to further reduce transmission of bTB between free-ranging deer and livestock. Such strategies are examples of straightforward management actions that producers can implement to help ensure biosecurity of their operations while generating a broader and healthier environment for neighboring wildlife populations. Our results demonstrated that exclusionary fences can reduce use and thus potential contamination of stored cattle feed by deer by at least $82.4 \%$, and induce a shift in deer use away from developed livestock-related areas, further decreasing potential for direct and indirect interaction between deer and livestock.

\section{Acknowledgments}

We are grateful to the USDA-APHIS-WS-MI, USDA-APHISVeterinary Services, USDA-APHIS-WS-NWRC, and MI Department of Agriculture and Rural Development (MDARD) for logistical and financial support. Mention of companies or commercial products does not imply recommendation or endorsement by the USDA nor does omission imply criticism. We also thank several individuals including R. Schanck, M. McCollum, D. Williams, G. Rigney, T. Aderman, A. Wilson, K. Pedersen, M. Lutman, E. Blizzard, S. Bevins, D. Marks, D. Arsnoe, S. Johnson, A. Berentsen, T. Ruby, and M. Watt for assisting with the project. Special thanks to private landowners that generously provided unlimited access to their land and animals during the study. We also appreciate the assistance and support provided by J. Kleitch from MI Department of Natural Resources, P. Butchko from USDA-APHIS-WS-MI, E. Sewell and R. Mellberg of the Alpena Conservation District-Natural Resources Conservation Service, and R. Smith of the MDARD. Thoughtful comments provided by D. O'Brien, H. Thulke, and an anonymous reviewer improved this article and are greatly appreciated. 


\section{References}

Atwood, T.C., Deliberto, T.J., Smith, H.J., Stevenson, J.S., VerCauteren, K.C., 2009. Spatial ecology of raccoons related to cattle and bovine tuberculosis in northeastern Michigan. J. Wildl. Manage. 73, 647-654.

Barasona, J., VerCauteren, K., Saklou, N., Gortazar, C., Vicente, J., 2013. Effectiveness of cattle operated bump gates and exclusion fences in preventing ungulate multi-host sanitary interaction. Prev. Vet. Med. 111, 42-50.

Barasona, J., Latham, M.C., Acevedo, P., Armenteros, J.A., Latham, A.D.M., Gortazar, C., Carro, F., Soriguer, R.C., Vicente, J., 2014. Spatiotemporal interactions between wild boar and cattle: implications for cross-species disease transmission. Vet. Res. 45, 122.

Benhamou, S., 2011. Dynamic approach to space and habitat use based on biased random bridges. PLoS ONE 6, e14592.

Benhamou, S., Cornelis, D., 2010. Incorporating movement behavior and barriers to improve kernel home range space use estimates. J. Wildl. Manage. 74 1353-1360.

Berentsen, A.R., Dunbar, M.R., Misiewicz, R., 2010. PVC curtains to prevent deer access to stored feed: a pilot study. In: Timm, R.M., Fagerstone, K.A. (Eds.) Vertebrate Pest Conference. Fort Collins, Colorado, pp. 315-318.

Berentsen, A.R., Miller, R.S., Misiewicz, R., Malmberg, J.L., Dunbar, M.R., 2013. Characteristics of white-tailed deer visits to cattle farms: implications for disease transmission at the wildlife-livestock interface. Eur. J. Wildl. Res. 60, 161-170.

Beyer, D., B. Rudolph, K., Kintigh, C., Albright, K., Swanson, L., Smith, D., Begalle, R. Doepker, Habitat and behavior of wintering deer in northern Michigan: a glossary of terms and associated background information. Michigan Department of Natural Resources and Environment, 2010. Wildlife Division Report 3520

Brook, R.K., 2010. Incorporating farmer observations in efforts to manage bovine tuberculosis using barrier fencing at the wildlife-livestock interface. Pre. Vet. Med. 94, 301-305

Cosgrove, M.K., Campa, H., Ramsey, D.S., Schmitt, S.M., O’Brien, D.J., 2012. Modeling vaccination and targeted removal of white-tailed deer in Michigan for bovine tuberculosis control. Wildl. Soc. Bull. 36, 676-684.

Daniels, M.J., Hutchings, M.R., Greig, A., 2003. The risk of disease transmission to livestock posed by contamination of farm stored feed by wildlife excreta. Epidemiol. Infect. 130, 561-568.

DeNicola, A.J., VerCauteren, K.C., Curtis, P.D., Hygnstrom, S.E., 2000. Managing White-tailed Deer in Suburban Environments - A Technical Guide. Cornel Cooperative Extension, Ithaca, New York.

Felix, A.B., Walsh, B.D., Hughley, H.I., Winterstein, S.R., 2007. Applying landscape-scale habitat-potential models to understand deer spatial structure and movement patterns. J. Wildl. Manage. 71, 804-810.

Fitzgerald, S., Kaneene, J., 2013. Wildlife reservoirs of bovine tuberculosis worldwide: hosts, pathology, surveillance, and control. Vet. Pathol. Online 50, 488-499.

Gehring, T.M., VerCauteren, K.C., Provost, M.L., Cellar, A.C., 2010. Utility of livestock-protection dogs for deterring wildlife from cattle farms. Wildl. Res. 37, 715-721.

Gilsdorf, J.M., Hygnstrom, S.E., VerCauteren, K.C., 2002. Use of frightening devices in wildlife damage management. Integr. Pest Manage. Rev. 7, 29-45.

Gortazar, C., Diez-Delgado, I., Barasona, J.A., Vicente, J., De La Fuente, J., 2015. The wild side of disease control at the wildlife-livestock-human interface: a review. Front. Vet. Sci. 1, 1-12.

Gulsby, W.D., Stull, G.R., Osborn, D.A., Warren, R.J., Miller, K.V., Tannenbaum, L.V., 2011. Movements and home ranges of white-tailed deer in response to roadside fences. Wildl. Soc. Bull. 35, 282-290.

Hill, J.A., 2005. Wildlife-cattle interactions in northern Michigan: Implications for theTransmission of BovineTuberculosis. Utah State University Thesis, Logan, Utah.

Judge, J., McDonald, R.A., Walker, N., Delahay, R.J., 2011. Effectiveness of biosecurity measures in preventing badger visits to farm buildings. PloS One 6, e28941.

Kilpatrick, H.J., Spohr, S.M., DeNicola, A.J., 1997. Darting urban deer: techniques and technology. Wildl. Soc. Bull. 25, 542-546

Knust, B., 2008. Reducing the public health impact of bovine tuberculosis by controlling disease transmission between cattle and white-tailed deer in northwestern Minnesota. University of Minnesota Thesis, Minneapolis, Minnesota.

Lavelle, M.J., VerCauteren, K.C., Hefley, T.J., Phillips, G.E., Hygnstrom, S.E., Long, D.B., Fischer, J.W., Swafford, S.R., Campbell, T.A., 2010. Response of deer to containment by a poly-mesh fence for mitigating disease outbreaks. J. Wildl. Manage. 74, 1620-1625.

Lavelle, M.J., Fischer, J.W., Hygnstrom, S.E., White, J.J., Hildreth, A.M., Phillips, G.E., VerCauteren, K.C., 2011. Evaluation of fences for containing feral swine under simulated depopulation conditions. J. Wildl. Manage. 75, 1200-1208.
Lees, V.W., 2004. Learning from outbreaks of bovine tuberculosis near Riding Mountain National Park: applications to a foreign animal disease outbreak. Can. Vet. J. 45, 28-34.

Miller, R.S., Sweeney, S.J., 2013. Mycobacterium bovis (bovine tuberculosis) infection in North American wildlife: current status and opportunities for mitigation of risks of further infection in wildlife populations. Epidemiol. Infec 141, 1357-1370.

O’Brien, D.J., Schmitt, S.M., Fitzgerald, S.D., Berry, D.E., Hickling, G.J., 2006. Managing the wildlife reservoir of Mycobacterium bovis: The Michigan, USA, experience. Vet. Microbiol 112, 313-323.

O'Brien, D.J., Schmitt, S.M., Fitzgerald, S.D., Berry, D.E., 2011. Management of bovine tuberculosis in Michigan wildlife: current status and near term prospects. Vet. Microbiol. 151, 179-187.

Okafor, C.C., Grooms, D.L., Bruning-Fann, C.S., Averill, J.J., Kaneene, J.B., 2011. Descriptive epidemiology of bovine tuberculosis in Michigan (1975-2010): lessons learned. Vet. Med. Int., 13.

Palmer, M., 2013. Mycobacterium bovis: characteristics of wildlife reservoir hosts. Transbound. Emerg. Dis. 60,1-13.

Palmer, M.V., Water, W.R., Whipple, D.L., 2004a. Shared feed as a means of deer-to-deer transmission of Mycobacterium bovis. J. Wildl. Dis. 40, 87-91.

Palmer, M.V., Waters, W.R., Whipple, D.L., 2004b. Investigation of the transmission of Mycobacterium bovis from deer to cattle through indirect contact. Am. J. Vet. Res. 65, 1483-1489.

Palmer, M.V., Whipple, D.L., 2006. Survival of Mycobacterium bovis on feedstuffs commonly used as supplemental feed for white-tailed deer (Odocoileus virginianus). J. Wildl. Dis. 42, 853-858.

Portacci, K., Lombard, J., Abrahamsen, L., Bush, E., Fossler, C., Harris, R., Johnson, K., Miller, R.S., Mitchell, D., Pritchard, R., 2009. Assessment of Pathways for the Introduction and Spread of Mycobacterium bovis in the United States. USDA APHIS VS CEAH, Fort Collins, Colorado.

Putman, R., Watson, P., Langbein, J., 2011. Assessing deer densities and impacts at the appropriate level for management: a review of methodologies for use beyond the site scale. Mamm. Rev. 41, 197-219.

Schauber, E.M., Storm, D.J., Nielsen, C.K., 2007. Effects of joint space use and group membership on contact rates among white-tailed deer. J. Wildl. Manage. 71, 155-163.

Schemnitz, S.D., Batcheller, G.R., Lovallo, M.J., White, H.B., Fall, M.W., 2009. Capturing and handling wild animals. In: Silvy, N.J. (Ed.), The Wildlife Management Techniques Manual. Johns Hopkins University Press, Baltimore Maryland, pp. 232-269.

Seward, N.W., Phillips, G.E., Duquette, J.F., VerCauteren, K.C., 2007. A frightening device for deterring deer use of cattle feeders. J. Wildl. Manage. 71, 271-276.

Sitar, K.L., 1996. Seasonal movements, habitat use patterns, and population dynamics of white-tailed deer (Odocoileus virginianus) in an agricultural region of northern lower Michigan. Michigan State University Thesis, Lansing, Michigan.

Tolhurst, B.A., Ward, A.I., Delahay, R.J., MacMaster, A.-M., Roper, T.J., 2008. The behavioural responses of badgers (Meles meles) to exclusion from farm buildings using an electric fence. Appl. Anim. Behav. Sci. 113, 224-235.

Tsukada, H., Takeuchi, M., Shimizu, N., 2010. Depredation of concentrated feed by wild mammals at a stock farm in Japan. Mamm. Study. 35, 281-287.

VerCauteren, K.C., Beringer, J., Hygnstrom, S.E., 1999. Use of netted cage traps for capturing white-tailed de. In: Proulx, G. (Ed.), Mammal Trapping. Alpha Wildlife Research \& Management Ltd., Sherwood Park, Alberta, pp. 155-164

VerCauteren, K.C., Pipas, M., Peterson, P., Beckerman, S., 2003. Stored-crop loss due to deer consumption. Wildl. Soc. Bull. 31, 578-582.

VerCauteren, K.C., Lavelle, M.J., Hygnstrom, S.E., 2006a. Fences and deer-damage management: a review of designs and efficacy. J. Wildl. Manage. 34, 191-200.

VerCauteren, K.C., Lavelle, M.J., Hygnstrom, S.E., 2006b. A simulation model for determining cost-effectiveness of fences for reducing deer damage. Wildl. Soc. Bull. 34, 16-22.

VerCauteren, K.C., Lavelle, M.J., Phillips, G.E., 2008. Livestock protection dogs for deterring deer from cattle and feed. J. Wildl. Manage. 72, 1443-1448.

VerCauteren, K.C., Seward, N.W., Lavelle, M.J., Fischer, J.W., Phillips, G.E., 2009. Deer guards and bump gates for excluding white-tailed deer from fenced resources. Hum. -Wildl. Confli. 3, 145-153.

VerCauteren, K.C. VanDeelen, T.R., Lavelle, MJ., Hall, W.H., 2010. Assessment of abilities of white-tailed deer to jump fences. J. Wildl. Manage. 74, 1378-1381.

Walter, W.D., Anderson, C.W., Smith, R., Vanderklok, M., Averill, J.J., Vercauteren, K.C., 2012. On-farm mitigation of transmission of tuberculosis from white-tailed deer to cattle: literature review and recommendations. Vet. Med. Int., 15.

Ward, A.I., B, Tolhurst, Delahay, 2006. Farm husbandry and the risks of disease transmission between wild and domestic mammals: a brief review focusing on bovine tuberculosis in badgers and cattle. An. Sci. 82, 767-777. 